\title{
Impact of Cluster Frontline Demonstration on Bridging Yield Gap of Toria (Brassica campestris) under Rainfed Condition in Tinsukia District of Assam
}

\author{
P. Amonge ${ }^{1 *}$, S. Bortahku' ${ }^{1}$ K. Borah ${ }^{1}$ and R. K. Saud ${ }^{2}$ \\ ${ }^{1}$ Krishi Vigyan Kendra, Assam Agricultural University, Tinsukia, India \\ ${ }^{2}$ Director of Extension Education (P\&I), Assam Agricultural University, Jorhat, Assam, India \\ *Corresponding author
}

\section{A B S T R A C T}

Keywords

Yield gap,

Technology gap,

Extension gap,

Technology index,

CFLD

Article Info

Accepted:

20 January 2021

Available Online:

10 February 2021
Toria (Brassica campestris) is one of the important Rabi crops in Tinsukia district of Assam but due to unavailability of improved variety and non adoption of improved cultivation practices, its productivity $(5.5 \mathrm{q} / \mathrm{ha})$ is far below the average national productivity (9.7 q/ha) and state average of $6.5 \mathrm{q} / \mathrm{ha}$. Krishi Vigyan Kendra, Tinsukia, Assam has conducted 77 demonstrations on Toria var. TS 67 and 100 demonstration on Toria var. TS 46 during the year in 2016-17 to 2018-19 in 30 ha and 40 ha area including eight villages of the district. The mean data of three years revealed that an average yield of $8.65 \mathrm{q} / \mathrm{ha}$ and $8.77 \mathrm{q} / \mathrm{ha}$ was recorded under cluster frontline demonstration plots of Toria var. TS 67 and TS 46, respectively over farmer's practice (6.8 q/ha). The percent increase in yield with both the varieties under demonstration over farmers practice was observed 27.29 and 29.01 percent. The average technology gap was recorded $1.35 \mathrm{q} /$ ha and 3.23 q/ha in case of Toria var. TS 67 and TS 46, respectively, while average extension gap was recorded $1.85 \mathrm{q} / \mathrm{ha}$ and $1.95 \mathrm{q} / \mathrm{ha}$. Average technology index of toria var. TS 67 and TS 46 was recorded 13.5 and 26.94 percent respectively.

\section{Introduction}

Oilseeds are important crops of Indian agriculture next to food grains in terms of acreage, production, and economic value. They share $15.07 \%$ of the gross cropped area and account for about 5\% of gross national product (GNP) and $10 \%$ of the value of all agricultural products (Choudhary, 2009). Rapeseed-mustard (Brassica spp.) is the third largest vegetable oilseed crop in the world after soybean and palm oil. India is one of the largest rapeseed-mustard growing countries in the world, occupying the first position in area $(5.76 \mathrm{~m} \mathrm{ha})$ and second in production $(6.82 \mathrm{~m}$ tonnes) after China. In Assam, toria is the only popular oilseed crop because of the prevailing climatic conditions and early duration of the crop, which enable the farmers to adopt summer crop after harvest of toria. Tinsukia district of Assam has a sizeable area under rapeseed-mustard cultivation with area and production 0.14 lakh ha and 0.10 lakh MT, respectively (Anonymous 2015). There are different high yielding varieties of toria recommended for Assam condition developed 
by Assam Agricultural University, Jorhat and other Agricultural Universities and Research Institutes under ICAR. In the present study two high recommended high yielding varieties viz., TS 67 and TS 46 has been demonstrated which are having higher potential yield than the varieties using by the farmers of the district. Keeping in view the present investigation attempts to study the yield gap between cluster front line demonstration technology and farmers yield, extent of technology adoption and benefit cost ratio.

\section{Materials and Methods}

Krishi Vigyan Kendra, Tinsukia, Assam has conducted cluster frontline demonstration on toria variety TS 67 and TS 46 during Rabi season under rainfed condition from 2016-17 to 2018-2019 under NMOOP. The demonstrations were conducted in farmer's field of eight different villages of Tinsukia district of Assam during in the year 2016-17, 2017-18 and 201819. For conducting CFLDs, a list of farmers was prepared from group meeting and specific skill training was imparted to the selected farmers regarding different aspect of cultivation. Farmers were provided training to follow the package and practices for rapeseed and mustard cultivation recommended by the Assam Agricultural University, Jorhat. A total of 77 and 100 numbers of practicing farmers were selected under CFLD on Toria var. TS 67 in 30 ha and TS 46 in 40 ha during 2016-17 to 2018-19. In case of Farmers practice, the traditional practices were followed by using existing varieties. The soil sample of the farmer's field was sandy loam in texture, low in organic carbon, available $\mathrm{N}$ and $\mathrm{K}$ contents but medium in $\mathrm{P}$ content with $\mathrm{pH}$ 5.1. Application of 40: $35: 15 \mathrm{~kg} / \mathrm{ha}$ each of $\mathrm{N}, \mathrm{P}_{2} \mathrm{O}_{5}$ and $\mathrm{K}_{2} \mathrm{O}$ along with $10 \mathrm{~kg}$ of borax was applied as basal.

The selected farmers under the CFLD were guided by KVK scientists in performing field operations like sowing, spraying, weeding, harvesting etc during the course of training and visits. The traditional practices were maintained in case of farmers practice. The data were collected from both from demonstration plots as well as control plot (farmers practice) and finally the extension gap, technology gap, technology index along with the economics were worked out (Samui et al., 2000) as given below.

Technology gap = Potential yield Demonstration yield

Extension gap $=$ Demonstration yield Farmer's yield

Technology index $=\frac{\text { Potential yield }- \text { Demo yield }}{\text { Potential yield }} \times 100$

\section{Results and Discussion}

It has been observed that in the CFLDs Toria variety TS 46 recorded the higher seed yield (8.9 $\mathrm{q} / \mathrm{ha})$ as compared to control $(6.6 \mathrm{q} / \mathrm{ha})$ with $34.85 \%$ increase in yield in the year 2018-19 (Table 2). However, the mean yield recorded in Toria var. TS 67 was $(8.65 \mathrm{q} / \mathrm{ha})$ with $27.24 \%$ increase in average yield over farmers practice (Table 1). The results are in conformity with the findings of (Hiremath et al., 2007; Kumar et al., 2010). From the results it is evident that the performance of demonstrated plot was found better than the farmers practice under same farming situation. The poor productivity in farmers practice might be mainly due to factors like use of non descript local variety, late sowing owing to late vacation of field after harvesting of medium to long duration winter paddy and low level of agronomic management in addition to non availability of resources in time. The result clearly depicts the positive effects of demonstrations over the existing practices towards enhancing the yield of toria in Tinsukia district. 


\section{Technology gap}

The average technology gap was recorded $1.35 \mathrm{q} / \mathrm{ha}$ in toria variety TS 67 and $3.23 \mathrm{q} / \mathrm{ha}$ in respect of TS 46 during the period of study (Table 1 and 2). The technology gaps recorded are ranged from 1.3 to $3.4 \mathrm{q} / \mathrm{ha}$ which reflects the farmer's participation in conducting the demonstration. The variation in technology gap observed might be due to dissimilarity in soil fertility and management factors in the district. Similar finding were recorded by Katare et al., 2011; Singh, 2017).

\section{Technology index}

The technology index showed the feasibility of evolved technology at the farmer's fields (Table 1 and 2). The lower value of technology index the more is the feasibility of technology. As such fluctuation in technology index (ranging from $13 \%$ to $28.3 \%$ ) during the study period in certain region may be attributed to the dissimilarity in soil fertility status, weather conditions and insect pest attack in the crop.

Table.1 Influence of CFLD yield, Technology gap, extension gap, technology index in Toria variety TS 67

\begin{tabular}{|c|c|c|c|c|c|c|c|}
\hline Year & $\begin{array}{c}\text { Potential } \\
\text { yield } \\
\text { (q/ha) }\end{array}$ & $\begin{array}{c}\text { CFLD } \\
(\mathbf{q} / \mathbf{h a})\end{array}$ & $\begin{array}{c}\text { FP } \\
(\mathbf{q} / \mathbf{h a})\end{array}$ & $\begin{array}{c}\text { \% } \\
\text { increase }\end{array}$ & $\begin{array}{c}\text { Technology } \\
\text { gap } \\
(\mathbf{q} / \mathbf{h a})\end{array}$ & $\begin{array}{c}\text { Extension } \\
\text { gap } \\
(\mathbf{q} / \mathbf{h a})\end{array}$ & $\begin{array}{c}\text { Technology } \\
\text { index }(\mathbf{\%})\end{array}$ \\
\hline $\mathbf{2 0 1 6 - 1 7}$ & 10 & 8.7 & 6.8 & 27.94 & 1.3 & 1.9 & 13 \\
\hline $\mathbf{2 0 1 7 - 1 8}$ & 10 & 8.6 & 7.0 & 22.86 & 1.4 & 1.6 & 14 \\
\hline $\mathbf{2 0 1 8 - 1 9}$ & 10 & 8.65 & 6.6 & 31.06 & 1.35 & 2.05 & 13.5 \\
\hline Mean & & 8.65 & 6.80 & 27.29 & 1.35 & 1.85 & 13.5 \\
\hline
\end{tabular}

Table.2 Influence of CFLD yield, Technology gap, extension gap, technology index in Toria variety TS 46

\begin{tabular}{|c|c|c|c|c|c|c|c|}
\hline Year & $\begin{array}{c}\text { Potential } \\
\text { yield } \\
(\mathbf{q} / \mathbf{h a})\end{array}$ & $\begin{array}{c}\text { CFLD } \\
(\mathbf{q} / \mathbf{h a})\end{array}$ & $\begin{array}{c}\text { FP } \\
(\mathbf{q} / \mathbf{h a})\end{array}$ & $\begin{array}{c}\mathbf{\%} \\
\text { increase }\end{array}$ & $\begin{array}{c}\text { Technology } \\
\mathbf{g a p} \\
(\mathbf{q} / \mathbf{h a})\end{array}$ & $\begin{array}{c}\text { Extension } \\
\text { gap } \\
(\mathbf{q} / \mathbf{h a})\end{array}$ & $\begin{array}{c}\text { Technology } \\
\text { index } \mathbf{( \% )}\end{array}$ \\
\hline $\mathbf{2 0 1 6 - 1 7}$ & 12 & 8.6 & 6.8 & 26.47 & 3.4 & 1.8 & 28.3 \\
\hline $\mathbf{2 0 1 7 - 1 8}$ & 12 & 8.8 & 7.0 & 25.71 & 3.2 & 1.8 & 26.7 \\
\hline $\mathbf{2 0 1 8 - 1 9}$ & 12 & 8.9 & 6.6 & 34.85 & 3.1 & 2.3 & 25.8 \\
\hline Mean & & 8.77 & 6.80 & 29.01 & 3.23 & 1.97 & 26.94 \\
\hline
\end{tabular}

Table.3 Economics of rapeseed-mustard under CFLD on Toria var. TS 67 vs. farmers practice

\begin{tabular}{|c|c|c|c|c|c|c|c|c|c|c|}
\hline \multirow[t]{2}{*}{ Year } & \multirow[t]{2}{*}{$\begin{array}{c}\text { Area } \\
\text { (ha) }\end{array}$} & \multirow[t]{2}{*}{$\begin{array}{l}\text { No. of } \\
\text { Demo }\end{array}$} & \multicolumn{2}{|c|}{$\begin{array}{l}\text { Cost of } \\
\text { Cultivation } \\
\text { (Rs/ha) }\end{array}$} & \multicolumn{2}{|c|}{$\begin{array}{l}\text { Gross Return } \\
\text { (Rs/ha) }\end{array}$} & \multicolumn{2}{|c|}{$\begin{array}{l}\text { Net Return } \\
\text { (Rs/ha) }\end{array}$} & \multicolumn{2}{|c|}{ B: C ratio } \\
\hline & & & CFLD & FP & CFLD & FP & CFLD & FP & CFLD & FP \\
\hline 2016-17 & 10 & 27 & 15430 & 14500 & 28710 & 22440 & 13280 & 7940 & 1.86 & 1.55 \\
\hline 2017-18 & 10 & 25 & 16120 & 15000 & 30100 & 24500 & 13980 & 9500 & 1.87 & 1.63 \\
\hline 2018-19 & 10 & 25 & 17900 & 16500 & 32870 & 25080 & 14970 & 8580 & 1.84 & 1.52 \\
\hline
\end{tabular}


Table.4 Economics of rapeseed-mustard under CFLD on Toria var. TS 46 vs. farmers practice

\begin{tabular}{|c|c|c|c|c|c|c|c|c|c|c|}
\hline \multirow[t]{2}{*}{ Year } & \multirow[t]{2}{*}{$\begin{array}{c}\text { Are } \\
\text { a } \\
\text { (ha) }\end{array}$} & \multirow[t]{2}{*}{$\begin{array}{l}\text { No. of } \\
\text { Demo }\end{array}$} & \multicolumn{2}{|c|}{$\begin{array}{c}\text { Cost of } \\
\text { Cultivation } \\
\text { (Rs/ha) }\end{array}$} & \multicolumn{2}{|c|}{$\begin{array}{c}\text { Gross } \\
\text { Return(Rs/ha) }\end{array}$} & \multicolumn{2}{|c|}{$\begin{array}{l}\text { Net Return } \\
\text { (Rs/ha) }\end{array}$} & \multicolumn{2}{|c|}{ B: C ratio } \\
\hline & & & CFLD & FP & CFLD & $\mathrm{FP}$ & CFLD & FP & CFLD & FP \\
\hline 2016-17 & 10 & 25 & 15430 & 14500 & 28380 & 22440 & 12950 & 7940 & 1.84 & 1.55 \\
\hline 2017-18 & 10 & 21 & 16120 & 15000 & 30800 & 24500 & 14680 & 9500 & 1.91 & 1.63 \\
\hline 2018-19 & 20 & 54 & 17900 & 16500 & 33820 & 25080 & 15920 & 8580 & 1.89 & 1.52 \\
\hline
\end{tabular}

Fig.1 Horizontal spread of Toria TS 67

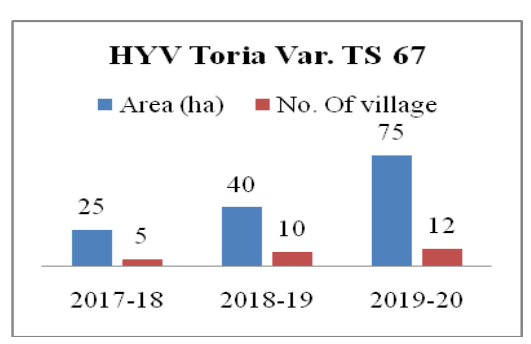

\section{Economics}

The higher cost of cultivation Rs. $17,900.00$ involved in CFLD plots during 2018-19 as compared to Rs. 16,500 under control plots (Table 3 and 4). The CFLD plots fetched higher gross returns (Rs.33,820.00 q/ha) and net returns in toria variety TS 46 (Rs. 15,920 q/ha) with higher benefit: cost ratio (1.89) during 2018-19 (Table 4). While in FP plots the gross returns, net returns and benefit: cost ratio were recorded Rs. 24,500, Rs.9,500.00 and 1.63 , respectively in the year 2017-18. It was also reported higher net returns and B: C ratio in the demonstrations due to on improved technologies compared to the farmer's practices.

\section{Horizontal spread}

Krishi Vigyan Kendra introduced the variety through cluster frontline demonstration during 2016-17, 2017-18 and 2018-19 at eight different villages of the district mainly in 3 blocks (Chepakhowa, Margherita and Saikhowa). The spread was recorded through
Fig.2 Horizontal spread of Toria TS 46

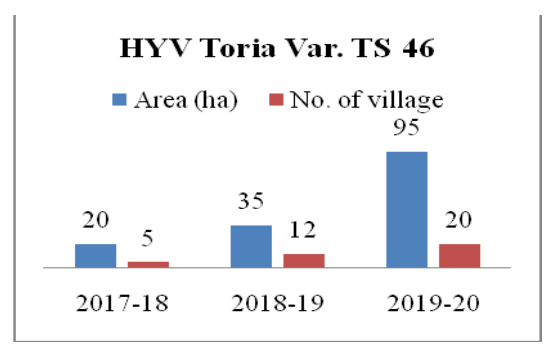

field visit, survey and group meeting. The horizontal spread of both the varieties TS 67 and TS 46 was 75 ha in 12 villages (Fig. 1) and 90 ha in 20 villages (Fig. 2) respectively in the district one year after the intervention i.e. during 2019-20.

It can be concluded that cluster frontline demonstration on toria variety TS 67 and TS 46 proved to the best in respect of yield, net return and benefit cost ratio. The findings of the study revealed that wide gap existed in potential and demonstration yield in high yielding rapeseed varieties due to technology and extension gap in Tinsukia District of Assam. By conducting cluster front line demonstrations of proven technologies, yield potential of rapeseed (toria) increased to a great extent. This will substantially increase the income as well as the livelihood security. Moreover, horizontal expansion of improved variety increased to a great extent within a short period of time due to various extension activities like training programme, field day, exposure visit etc. organized in CFLD programmes in the farmer's fields. 


\section{References}

Anonymous, 2015. Statistical handbook Assam, Directorate of Economics and Statistics, Government of Assam.

Choudhary, A.K., 2009. Role of sulphur in oilseeds and its management. Indian Farmers' Digest. 42(12): 9-12.

Hiremath, S.M., M.V, Nagaraju and Shasidhar, K.K. (2007). Impact of frontline demonstration on onion productivity in farmer's field. Paper Presented In: Nation Sem Appropriate Extn Strat manag Rural Resource, Univ. Agric. Sci., Dharwad, December 18-20, Pp. 100.

Katare, S., S.K, Pandey and Mustafa Mohd. 2011. Yield gap analysis of rapeseedmustard through front line demonstrations. Agric. Update. 6(2): 5-
7.

Kumar, A., R. Kumar, V.P.S. Yadav and Kumar, R. 2010. Impact assessment of frontline demonstrations of bajara in Haryana state. Indian Re. J Ext. Edu. 10(1):105- 108.

Samui, S.K., S. Maitra, D.K. Roy, A. K. Mandal and Saha, D. 2000. Evaluation of front line demonstration on groundnut. J. Indian Soc. Coastal Agri. Res. 18(2): 180-183.

Singh, S. B., 2017. Yield Gap Analysis of rapeseed-mustard (Brassica compestris) through front line remonstrations under Rainfed condition in Uttarakhand. ECHNOFAME- A Journal of Multidisciplinary Advance Research. 6(1): 89-92.

\section{How to cite this article:}

Amonge, P., S. Bortahku, K. Borah and Saud, R. K. 2021. Impact of Cluster Frontline Demonstration on Bridging Yield Gap of Toria (Brassica campestris) under Rainfed Condition in Tinsukia District of Assam. Int.J.Curr.Microbiol.App.Sci. 10(02): 2797-2801. doi: https://doi.org/10.20546/ijcmas.2021.1002.309 